\title{
Realizing Learner Autonomy in Pakistan: EFL Teachers' Beliefs about Their Practices
}

\author{
Musarat Yasmin ${ }^{1,2} \&$ Ayesha Sohail ${ }^{2}$ \\ ${ }^{1}$ Department of English, University of Gujrat, Gujrat, Pakistan \\ ${ }^{2}$ Department of English, University of Azad Jammu and Kashmir, Muzaffarabad, Pakistan \\ Correspondence: Musarat Yasmin, Department of English, University of Gujrat, Gujrat, Pakistan. E-mail: \\ musaratalvi@hotmail.com
}

Received: October 26, 2017 Accepted: November 18, 2017 Online Published: December 23, 2017

doi:10.5539/ijel.v8n2p153 URL: http://doi.org/10.5539/ijel.v8n2p153

\begin{abstract}
Learner autonomy (LA) has been a key area of interest in foreign language learning and teaching for more than three decades, but a limited space has been awarded to the investigation of teachers' practices in fostering LA. Following an interpretive paradigm and a qualitative approach, present study intended to unearth the strategies teachers of English use to make their learners autonomous. Data were collected through semi-structured interviews with sixteen English teachers from four public universities of province Punjab. Findings revealed that, in general, teachers use teacher-centered approach while participants' practices and use of various strategies showed their preference for the role of facilitator more than of counselor or resource. Results of this research imply that the goal of LA can be achieved through offering teachers training to make them aware of the significance of making their learners autonomous and incentives for the promotion of LA in their classroom.
\end{abstract}

Keywords: student-centered learning, role of teacher, English as foreign language, classroom practices, learner autonomy

\section{Introduction}

\subsection{Learner Autonomy}

An interest in learner autonomy (LA) has been witnessed growing for last more than 30 years. With an earlier individualistic tone in the form of self-learning in mid-seventies was replaced by a focus on fostering autonomy in the classroom by equipping learners with all required skills, particularly needed in language learning. Consequently, the teachers' role emerged to be more critical than ever demanding a drastic modification in prevailing traditional pedagogy. Teachers were required to take diverse roles of facilitator, counselor, and resource-person (McDevitt, 1997; Yang, 1998; Feryok, 2013; Bajrami, 2015) and to change their behavior: from controlling to autonomy-supportive (Ryan \& Grolnick, 1986; Reeve et al., 2004; Reeve, 2006).

Nevertheless, it needs to be examined whether English teachers recognize their new role and required strategies which could address the need. A little research is available conducted in few parts of Asia and Europe. Sub-continent, being the largest part of Asia is left to be explored. Moreover, Pakistan that shares few colours with other Asian countries, exhibit its own unique culture which is a combination of various shades: religious impact of Arab, a long shared historical traces of Indian culture and post-colonial influence of Britain (Khilji, 2003; Yasmin et al., 2015). Blended culture exerted its impact on the minds and lives of its people in the form of traditional family and cast system taken from Indian culture, and class system from British colonization. Like other fields, it influenced education system also where surrendering to authority is valued and originality and independence are met with disapproval.

\subsection{Significance of Research}

Pakistan is a multilingual country with no less than 25 languages (Mansoor, 2005) where Urdu as national and English as official language (Yasmin et al., 2016). With a colonized past, Pakistani society suffers from acute class division and class consciousness; hence, English enjoys a status on the expense of local languages. Despite several efforts to promote Urdu recently, English is used widely in government, higher education, judiciary and official business. The English language is considered a passport to success in acquiring employment and social mobility. Moreover, compulsory courses like communication skills are taught to enable learners to grab 
opportunities of higher education and employment. Higher Education Commission ( HEC) established English Language Teaching Reform (ELTR) project in 2004 with an investment of PKR $38.39 \mathrm{~m}$ in phase-I and PKR $53.67 \mathrm{~m}$ in Phase II in 2010 (Ahsan \& Anjum, 2012). Five self-access centers were also established. ELTR organizes workshops for professional development of English teachers in all provinces where 2,798 participants are declared as trained till 2016 (source HEC official website). It should be noted here that LA has never been considered a goal yet in any of these workshops. It is, however, vague whether Pakistani teachers have an understanding of their role in promoting autonomy in their learners and what their actual practices are. Present study intended to address this gap by examining their perceived practices in the classroom where communication skills are being taught to all disciplines. Identification of teachers' practices would be vital as the results may help understand actual situation and may provide a basis for proposing practical implications for ELTR in future.

\subsection{Relevant Scholarship}

\subsubsection{Teachers' Role}

Teachers have a key role in promoting LA (Benson, 2011). A misconception related to LA came in vogue due to individualistic tone of definition pronounced by Holec (1981) where learners was called autonomous if they have an ability, willingness (Dam, 1995) and control (Benson, 2011) over his decisions regarding defining objectives, determining content and selecting method and monitoring and evaluation. However, Esch (1998, p. 37) stated explicitly "it is not self-instruction/learning without a teacher... it does not mean that intervention or initiative on the part of a teacher is banned". This led to negation of teachers' role of omniscient causer of learning or someone to listen to or obey blindly; rather they are resource to give advice, help learners find material, suggest procedures (Holec, 1987). Developing LA was considered teachers' responsibility and in absence of whom, "the whole process will result in low efficiency or even fall into disorder" (Yan, 2012, p. 559). Yang's (1998) study denied the misconception of teachers' minimised role in LA. Study showed that learners in this study were unable to set realistic goals, required self-discipline, and their initial selection of strategies was affected by their inaccurate beliefs. It was gathered that presence of teacher was necessary to help students in setting realistic aims and guiding about appropriate strategies needed. Another study of Feryok (2013) showed an improvement in learners' performance as they learnt to maintain their rights to choose or refuse as a result of teacher-provided learner involvement in controlling, choosing, and modeling activities. Feryok (2013) concluded that neither a complete absence nor complete teacher guidance but little teacher-scaffolding was necessary to make learners autonomous. Alzubi \& Singh (2017) also showed that learners prefer to use social strategies as they might feel better and confident working with others.

Self-determination theorists believed learners to possess inner motivational resources, and that can be cultivated or neglected by learning situations where teacher plays a major part (Reeve, 2006). Research showed that successful learning is a result of mutual engagement of learners and teachers in learning process and learners were found motivated and active in participation in an autonomy-supportive environment provided by teachers (Ryan \& Deci, 2000). If the positive educational outcome is the goal, the new role of teachers requires them to reconsider the power structure between them and learners (Little, 1991). According to researchers and theorists, new roles of an autonomy-supportive teacher are a facilitator, counselor and resource person (Holec, 1987; Higgs, 1988; McDevitt, 1997; Voller, 1997; Camilleri, 1997; Little, 2004). The facilitator was defined as one who offers psycho-social and technical assistance. A resource person was called one who offers students with information when required. Camilleri (1997, p. 37) expanded information to a complete range of strategies and learning styles. A counselor is one who responds meaningfully to learners' problems to make the learning problem smooth.

Reflecting on autonomy supportive teaching style, Reeve (2006) listed a set of assumptions about teachers' role as: nurturing learners' motivation by building teaching activities on learners' preferences, using non-controlling informational language, communicating the value of the task that has little interest to learners or what McDevitt (1997) termed connecting process with objectives or what Assor et al. (2002) called fostering relevance, accommodating learners' expression of negative effect, having an autonomy-supportive behaviour. Last mentioned assumption is comprised of a number of class practices included: listening to students carefully, helping learners taking initiative (McDevitt, 1997), working in their preferred style, and using a variety of resources, providing opportunities to interact and use language, appreciating learners' efforts and improvement, scaffolding learners when they require, accepting and responding to learners' opinion and queries respectively (Deci et al., 1982; Ellis \& Sinclair, 1989; Reeve et al., 1999; Assor et al., 2002).

A comparison of learners taught by both controlling as well as autonomy-supportive teachers, learners with teachers of latter category exhibited enhanced motivation (Ryan \& Grolnick, 1986), an increased perceived 
competence (Deci et al., 1981), improved conceptual understanding (Benware \& Deci, 1984), better performance (Boggiano et al., 1993), acceptance for challenging success (Shapira, 1976), enhanced involvement (Reeve et al., 2004) and greater creativity (Koestner et al., 1984).

\subsubsection{Teachers' Practices}

Interest to explore teachers' practices to promote LA emerged recently in present decade (Balciknali, 2010; Nakata, 2011; Borg \& Busaidi, 2011; Duong \& Seepho, 2014; Nasri et al., 2015; Xu, 2015; Dwee et al., 2017). A small number of studies are available to inform the trend.

Balçıanlı (2010) investigated the perceptions of student teachers of English in Turkey to find the desirability level to which they feel like involving their learners in decision making. Besides a survey of 112 student teachers, 20 more were interviewed in focus groups. Findings showed that student teachers were very positive about the involvement of students in decisions about formulating long and short objectives, though, again, they did not display eagerness about involving students in decisions about selecting textbooks, discipline matters, type, and frequency of home-task. Then, Nakata (2011) examined teachers' readiness for promoting LA by exploring perceptions of 80 Japanese school teachers teaching English about their perceived importance and perceived strategy use for the purpose. A mixed method study employing survey and focus group discussion (FGD) showed that all mentioned strategies were found underutilized as compare to the importance attached and least utilized strategy was helping learners to discover knowledge on their own without waiting for the teacher while strategies like giving learners chances to express an opinion in learning and learning from peers were found least important and least utilized. The researcher concluded that teachers were not ready to undertake the task of promoting LA. In a similar vein, Borg \& Busaidi (2011) studied English teachers' perceptions and practices in Omani context through survey and semi-structured interviews. Results revealed that learner involvement in decision making was considered desirable more than feasible due to constraints. Teachers were found informing learners about the significance of LA, encouraging learners to reflect on, using student-centered activities along out-of-class activities. This gap of desirability and teachers' actual practices was found again recently by Xu (2015) who studied students' beliefs about their teachers' practices and found that despite the potential in teachers' role in promoting autonomy as learners perceived, learners found teachers' practices in less conformity with their expectations.

Another study on teachers' perceptions and practices was conducted by Duong \& Seepho (2014) who employed an open-ended questionnaire and interview with 30 and eight EFL teachers respectively in a Thai Public university. The role of facilitator received more response than that of counselor or resources provider. Reported practices included providing learners with opportunities to work independently by inspiring students to find resources by themselves, asking students to reflect upon their performance, giving them a task to practice, asking them to select a topic, learning strategies, and learning materials of their choice. Teachers also mentioned that they have to force learners to follow due to lack of learner motivation that shows a contrast between teachers' perception and their actual classroom practices.

Nasri et al. (2015) conducted a class observation of 42 teachers in Iranian high school to find classroom practices. Major themes included focusing on learner independence, giving a choice to learners, providing learners opportunities to learn from each other, and setting out-of-class activities. Teachers were found asking learners to teach or describe the previous lesson, giving learners a choice in selecting topic and order of teaching, asking them to work in groups, to look for meaning or rule, and to evaluate each other's work. A small-scale study was conducted by Dwee et al. (2017) who studied English teachers' perceptions, practices and challenges in the promotion of LA through a semi-structured interview with five respondents. Teachers reported to activate learners' prior knowledge, encourage learner interaction and group work, provide freedom of choice to learners and select challenging tasks for learners.

Above first four studies showed that teachers, though the desire to enable learners to be autonomous, yet were not found practicing strategies at large. Duong \& Seepho (2014) found a list of perceived use of strategies, but in doing so, teachers admitted to forcing learners to follow teachers' agenda. Teacher practices found in above studies included some potential strategies like informing the significance of LA, promoting reflection by encouraging goal-setting, encouraging collaborative work and giving a choice. Results also showed that except one study, giving a choice was debated and a surface-level choice seems to be acceptable e.g., in topic selection. Lack of extensive empirical evidence makes it hard to understand the viability of autonomy and possible variety of autonomy-supportive behaviors teachers can employ. Furthermore, teachers need to understand the possible roles they need to perform to make their learner autonomous particularly in countries like Pakistan where the traditional teacher-centered approach is used in all public institutions. It needs to be investigated that teachers 
who themselves have not experienced learner autonomy in student life or even teacher autonomy in professional life can understand the need of LA promotion and how far they can practice it in their classes. In a country where LA is considered a new phenomenon (evidence from the main study), a qualitative approach was considered appropriate to unearth the perceptions before proceeding to any experimental study initially. Present study intended to explore teaching strategies employed in classes to make learners autonomous and the role performed by these teachers. Results of this study will inform HEC to reconsider their focus in professional development.

\subsection{Research Question}

Following are the research questions that guided this research.

1) What is the role of English teachers to promote LA?

2) What are the teaching practices of English teachers to promote LA in Pakistani universities?

\section{Method}

Following an interpretive paradigm, researchers intended to investigate the meaning participants attached to their practices in LA development. Autonomous learning was operationally defined for the present study on the lines of Holec (1981), "Learning that involves and enables the learner to understand and decide about goals, learning content and method, and monitoring and evaluation."

\subsection{Participants}

English teachers teaching communication skills in public universities of province Punjab were targeted as population. Participants were selected by their experience and academic background in English literature or language. Half of these participants were less experienced with teaching experience of fewer than five years while others with more than five years teaching experience were considered experienced. It should be clear that selected criterions were used to make the sampling systematic and were not intended to use as a construct. Single-sex and single-discipline universities were excluded as directed by the main focus of interest.

All participants were informed about the nature and procedure of research and were asked to sign a consent form mentioning the voluntary nature of participation. Pseudonyms in the form of random alphabets were used replacing original names to ensure participants' confidentiality.

\subsection{Sampling Procedures}

Purposive sampling was conducted twice. First, four universities including Punjab University Lahore, Government College University Lahore, University of Gujrat, and the University of Education were selected by being the oldest and youngest institutes. Second, sixteen teachers (RJ, AP, JJ, RM, IG, SH, SM, SS, KN, MN, SB, FM, MA, ZK, SJ, MI) teaching a compulsory three credit-hours course of communication skills to BS learners of all disciplines in these universities were selected.

\subsection{Measures and Covariates}

In order to address the research questions, teachers' views were explored in detail by following a qualitative approach to employing semi-structured interviews. Flexibility was maintained in the sequence and phrasing of questions to be determined by the flow of interview as was suggested by Bailey's (2007). Formulation of questions was guided by relevant literature on LA and research question (see Appendix A). Individual interviews in the main study lasted for 40-60 minutes each, were audio-recorded, and later transcribed. Class-observations were made for four classes to understand actual practices; however, the present article focused on results related to teachers' beliefs about their role and practices.

An inductive approach to constant comparison was followed, and data were analyzed thematically as suggested by Creswell (2003). Multiple readings of the data helped the researchers initially to identify the codes (Hesse-Biber \& Leavy, 2006) and then reduce them to themes. Besides acknowledging the themes from existing literature, coding was kept open to identify reality-reflective themes as perceived by participants. Themes were interpreted to ensure the level of fairness as suggested by Lincoln \& Guba (1985) to ensure a balance between the voices of different stakeholders: participants and researchers.

Present research used various ways to achieve trustworthiness as Lincoln \& Guba (1985) suggested. These included sending transcripts back to respondents to validate the truthfulness of data, using the rich verbatim interpretation of respondents' accounts and triangulating the data in the main study.

\section{Results and Discussion}

Respondents' views regarding English teachers' practices of fostering LA, two major themes emerged: overall English teachers' practices and participants' classroom practices. 


\subsection{English teachers' practices of promoting LA in Pakistan}

Participants' perceptions portrayed a gloomy picture as all of them viewed LA absent from Pakistani educational system generally and from teachers' practices particularly. One of the participants, MI, called existing LA practice as "Slightly, slightly better than zero" which another respondent, SJ, explained in words, "unfortunately this autonomous culture is not very much vogue in our classrooms." The present situation was brought to light as under.

\subsubsection{Practicing Traditional Approach}

A majority of practicing teachers was reported as traditional following teacher-directed and teacher-centered approach with few exceptions as IG found. According to another participant MI, traditional practices reflected from teachers' intolerance towards difference of opinion and their stress on learners to follow what they think right. A standard set by a teacher, even in varieties of English, was reported as forbidden by these teachers. SB explained this attitude concerning Asian culture where a teacher enjoys a status of authoritative and the most knowledgeable figure. Paradoxical to the essence of LA that demands for learner confidence to help them in making decisions, Pakistani teachers were called as confidence killers by one participant MI,

"if you speak fluently they will go after you for your pronunciation; if you pronounce in a reasonably good way, they will ask you to go for British or American... they are killing so much energy among students and more damaging is the death of the confidence among students. Trust me, this is so detrimental, this is so sorry to see that many of good students they never think that they could learn it".

Besides intolerance and authoritative attitude, another teaching-learning cultural practice of traditional teaching, which stems from two practices mentioned above, was reported by SJ as cramming. It can, however, be related to an educational system that focuses on completing given contents at a fixed time, as SJ also realized later. An authoritative, intolerant teaching pedagogy with a focus on cramming could be detrimental not only for learners' creativity and curiosity but also for LA at large as teachers' ideological baggage restricts LA development.

\subsubsection{Focusing on Correcting Error}

A common practice of Pakistani teachers originates from intolerance towards learners' mistakes and errors. MI called teachers to be quite descriptive with a whole concentration on correcting errors instead of allowing learners to find mistakes themselves and learn, hence, he felt, "autonomy is a remote goal in this sense... if you just by chance slip a word, you mispronounce the word or say it in grammatically wrong fashion teacher thinks it's his job to jump in and correct it and for that he might have to compromise on a bigger idea ...".

\subsubsection{Discourage Learner Inquiry}

Pakistani teachers discourage learner inquiry, an obvious output of a teacher-directed classroom, as reported by some participants. MI perceived teachers threatened of learner inquiry and expressed his lack of trust in the viability of LA in such situation. Another participant, RJ shared her reflection of the effects of this approach on learner motivation as she observed a learner losing interest and found on inquiry that he was snubbed in other teachers' classes for asking questions. A learner inquiry, here, is not a sign of learner's quest for information, rather a sign of rudeness where teachers are heard saying "buht hi badtameez hai, buht hi gustaakh hai" (very rude, very presumptuous).

\subsection{Individual Practices}

When participants were asked about their teaching practices in promoting LA, few of them openly confessed that they had been a traditional teacher. Their responses led to 13 class practices as illustrated in Table 1. 
Table 1. Pakistani English teachers' class-practices of LA

\begin{tabular}{|c|c|c|c|}
\hline & Practice & Respondents & Illustration \\
\hline 1 & A traditional teacher & RM, FM, MA & $\begin{array}{l}\text { "I am a pretty old-fashioned teacher, a lecturer who goes to the class, delivers } \\
\text { the lecture and comes out. So far it has worked because the kind of students } \\
\text { that I get they are not very autonomous. So, I feel that ... I need to tell them } \\
\text { each and everything" (RM) }\end{array}$ \\
\hline 2 & $\begin{array}{l}\text { Creating awareness } \\
\text { among learners }\end{array}$ & MI & $\begin{array}{l}\text { "campaigning to take their autonomy, to utilize their autonomy and learning } \\
\text { and make themselves independent learners." (MI) }\end{array}$ \\
\hline 3 & $\begin{array}{l}\text { Encouraging } \\
\text { independence }\end{array}$ & IG, RM, MI & $\begin{array}{l}\text { (I say), "NO! I will not suggest you a topic. What you can do is.... Bring in a } \\
\text { topic, and I will help you refine that topic" (IG) }\end{array}$ \\
\hline 4 & $\begin{array}{l}\text { Encouraging learner } \\
\text { inquiry and allowing them } \\
\text { to hold views }\end{array}$ & $\mathrm{KN}, \mathrm{SH}, \mathrm{SJ}$ & $\begin{array}{l}\text { "I respect my students and their opinion about things. I give them space to } \\
\text { question things, to have an opinion about things. I do not snub them." (KN) }\end{array}$ \\
\hline 5 & Encouraging creativity & $\mathrm{RM}, \mathrm{SM}$ & $\begin{array}{l}\text { "I plan actually the way, in which they are supposed to express their ideas in } \\
\text { an unknown situation or different situation-A situation to which they have not } \\
\text { been exposed before" (SM) }\end{array}$ \\
\hline 6 & $\begin{array}{l}\text { Helping learners } \\
\text { becoming confident }\end{array}$ & $\mathrm{SB}, \mathrm{SJ}, \mathrm{JJ}$ & $\begin{array}{l}\text { "not only boost up their confidence rather they become true individuals as far } \\
\text { as their passion for learning is concerned" (SB) }\end{array}$ \\
\hline 7 & Motivating learners & IG, FM, JJ, MA & $\begin{array}{l}\text { "Whenever I feel that they have started losing interest, I resort to my poetical } \\
\text { action and I just recite one or two couplets that engage them into the } \\
\text { discussion immediately for some reason". (FM) }\end{array}$ \\
\hline 8 & $\begin{array}{l}\text { Helping learners in } \\
\text { developing (meta) } \\
\text { cognitive skills }\end{array}$ & $\mathrm{SH}, \mathrm{SJ}$ & $\begin{array}{l}\text { "I ask them to write an essay or paragraph and then, I ask them to become } \\
\text { their own teachers and check that thing... and then I asked them to shuffle their } \\
\text { writings and their fellows to mark other fellow's essay or paragraph or } \\
\text { whatever they wrote." (SH) }\end{array}$ \\
\hline 9 & $\begin{array}{l}\text { Giving choice in selecting } \\
\text { topic }\end{array}$ & FM, IG & $\begin{array}{l}\text { "I sometimes do is, I open the choice for them ... they come up with their novel } \\
\text { ideas" (FM) }\end{array}$ \\
\hline 10 & $\begin{array}{l}\text { Helping learners in } \\
\text { collecting material }\end{array}$ & MA, MI & $\begin{array}{l}\text { "I give them a task and ask them to go home and research on that particular } \\
\text { item or term and they come in the next class after writing a paragraph or two } \\
\text { on that. I take that as their quiz sometimes". (MI) }\end{array}$ \\
\hline 11 & $\begin{array}{l}\text { Engaging learners in } \\
\text { collaborative tasks }\end{array}$ & RM, RJ, MA, SJ & $\begin{array}{l}\text { "after that discussion.... each group is supposed to come in front of the class } \\
\text { and they actually tell the class that what different aspects related to the issue } \\
\text { they have discussed". (MA) }\end{array}$ \\
\hline 12 & $\begin{array}{l}\text { Providing opportunities to } \\
\text { use language }\end{array}$ & MA & $\begin{array}{l}\text { "mock interviews are there in the class room where students tried to see the } \\
\text { suitability of a candidate who comes before the panel with his cv". (MA) }\end{array}$ \\
\hline 13 & $\begin{array}{l}\text { Giving out-of-class } \\
\text { activities }\end{array}$ & MI, MA & $\begin{array}{l}\text { "...ask them to listen to some particular TV programs it must be....instead of } \\
\text { saying in straightway it's an activity for you" (MI) }\end{array}$ \\
\hline
\end{tabular}

Pakistani teachers' perceived practices of other English teachers overall seem to draw on behaviorists approach where errors were regarded as sins (Larsen-Freeman, 1986; Lightbown \& Spada, 1990), and practitioners and theoreticians favored correcting mistakes immediately as "errors lead to the formation of bad habits" (Larsen-freeman, 1986, p. 40). In contrast, followers of cognitive approach believed it natural to make errors which would disappear through communication without intimidating learners with correction (Truscott, 1996). Research showed quite earlier that "overcorrection can destroy a student-teacher relationship," (Pehrsson \& Robinson, 1985), "put(s) the learner on defensive" (Ommagio, 1986, p. 282) as he/she has nothing acceptable to communicate but present finding shows contended behaviorist pedagogy in practice. Pakistani English teachers' emphasis on correcting mistakes might negatively affect students' self-confidence.

On learner side, efforts of few teachers to make their learners aware of what is required of them in an autonomous class is not only appreciable but also is in line with Little $(1995$, p. 178) who felt that success of LA development depends on "nature of pedagogical dialogue." Teacher-learner negotiation to inform learner about the value of LA was also found as a practice in some Omani teachers in the study of Borg \& Busaidi (2011).

Besides awareness, learner needs to develop skills and attitudes to become autonomous. Participants shared their practices of helping learners to be confident and creative, avoiding plagiarising other's thoughts (RM). To achieve this, the learner will have to be taken as an individual mind, and his/her right of opinion should be respected. Few participants were reported to stimulate learners to have their voice to inculcate a thirst for knowledge in them unlike teacher practices in Nakata (2011) and Nasri et al. (2015) where former researcher informed that learners' right of opinion was least desired and least practiced. For the purpose mentioned above, an overall learner-friendly environment is necessary for freedom of speech. One participant SH informed to guarantee a learner-friendly environment in his class. From one participant's practice of providing real-life situations, researchers infer that reported behavior may help in internalizing the knowledge and help learners deal with real-life problems later in their practical lives. As researchers feel that good teachers, like parents, 
should understand that they are with their learners for a short period, so they try to equip them with necessary skills (McDevitt, 1997).

Motivating learners was found a common practice among participants to enable the learner to become responsible for learning and various ways were reported to do so like using literature to recapture learners' diverted attention, and by following learners' preferences and interests in creating class activities. The present finding seems to follow what Reeve's (2006) suggested in his study to follow learners' inner resources (preferences and interests) while building class activities and which was supported by recent findings of Jang et al. (2016). They showed that learners whose preferred styles of learning were followed in the treatment group showed greater autonomy satisfaction, greater engagement, and greater conceptual learning as compared to learners in control group. Learners can be motivated extrinsically through rewards as one participant JJ shared his experience. It should be noted here that rewards may motivate learners extrinsically, but they may not work to stimulate learner for lifelong learning as Reeve (2006) also suggested depending on inner resources not on external regulators.

Few participants shared about their practice of providing learners for utilizing their metacognitive skills, one of them quoted his practice of asking learners to evaluate themselves as was found in Nasri et al. (2015). A large number of researchers like Ellis \& Sinclair (1989), Ng \& Confessore (2010), Ushioda (2011) and Nguyen \& Gu (2012) found a potential a role of learners' skills in developing LA. However, the participant did not inform whether he used to provide certain evaluation criterion or guide them how to evaluate.

Some participants reported providing CL opportunities including interactive exploratory task, engagement in discussion and enactments. It was believed that collaborative tasks are found helpful in developing critical thinking skills. Besides, being an incentive for exploration, interaction, CL benefit learners in developing rapport which enhances team spirit and enhances sharing of knowledge. Previous studies like Nasri et al. (2015) and Dwee et al. (2017) found group works beneficially in promoting LA through learners' involvement in their learning process.

Few participants were found offering their learners out-of-class activities to search different resources or activities where they would learn on their own. Involvement of learners in out-of-class activities was suggested by earlier studies of Balcikanli (2010) and Borg \& Busaidi (2011) where latter found one participant reporting his practice of giving an assignment to learners which demands to search and surfing different resources. Duong $\&$ Seepho (2014) also found one of the teacher-respondents' reporting asking learners to access various resources themselves. All these studies along with present finding show that teachers understand the importance of learner involvement in out-of-class activities, but a gap of desirability and practice is quite large. Moreover, respondents, who viewed their practices quite traditional, explained concerning the barriers they felt that were imposed by the educational system, confirming the results of Borg \& Busaidi (2011) where 10\% teachers disagreed that they develop LA and they linked their lack of practice to the constraint forced by the educational system. Conversely, participants of present research showed a mixed attitude towards enhancing learners' individuality and his/her participation in CL where respondents in the study mentioned had more dispositions towards individualistic approach.

\subsection{Role of Teachers}

Findings revealed that teachers are exercising three roles as Facilitator, counselor and resource as were signified by researchers (Voller, 1997; Little, 2004) and studies on teacher's roles confirmed its understanding (Camilleri, 1997; Yan, 2012; Duong \& Seepho, 2014; Bajrami, 2015). Participants were found more inclined to the role of facilitator as was found in Duong \& Seepho (2014) (through creating awareness, encouraging learners to be independent, encouraging creativity, encouraging learners holding views, helping in building confidence, motivating learners, helping in developing (meta) cognitive skills, considering learners' preferences, providing a real-life situation, engaging in collaborative activities, providing the learner-friendly environment, and asking learners to access different resources than towards the role of the resource (through providing initiatives and helping in collecting material) or as a counselor (through giving suggestion and feedback).

With these practices, learning situation seems promising as respondents reported an autonomy-supportive behavior as was advised by Deci et al. (1982) and Reeve et al. (1999), however, the quite low frequency of participants practicing make the picture gloomy particularly less common practices were found emphasized by researchers like (McDevitt, 1997; Reeve, 2006; Yasmin et al., 2017; Yasmin \& Sohail, 2017). Some other critical suggestions were found completely missing in Pakistani teachers' practices like use of non-controlling language, communicating the value of the task as well as autonomous learning (McDevitt, 1997; Reeve et al. 1999), acknowledging learners' expression of negative effect (Assor et al. 2002). A detailed look at their actual practices 
in the classroom would further help in making the situation clear.

\section{Conclusion}

The present study explored teachers' views about their practice regarding developing autonomy in their learners. Findings showed that teachers' most common practices included following teacher-directed pedagogy, encouraging learners to become confident, motivated, independent, and work with peers. Some other less commonly practiced behaviors included encouraging creativity and learner inquiry, offering freedom of choice in selecting a topic for discussion, creating awareness, helping learners in developing skills of identifying goals and planning, providing opportunities to use language, and giving learners out-of-class activities.

The purpose of this study was to explore how LA was being translated into teachers' present practices. As the purpose was to understand the type of possible practices, so the frequency of each practice was not considered the focus of this study, hence ignored. However, the frequency of practices led researchers to believe that certain practices were perhaps more viable and famous in teachers than others while latter was equally critical in developing LA. A comparison of present finding with previous highlighted the lack of certain practices in Pakistani teachers. The study, therefore, implies the need of teacher-training to enable them to have a clear understanding of the nature of LA and the ways a teacher can translate their understanding into their classroom practices.

The present study has contributed to the field of LA through uncovering teachers' understanding of their role and practices in the Pakistani context. As present results are self-reports, so, an objective observational study is required to bring actual practices to light.

\section{References}

Ahsan, N. M., \& Anjum, T. (2012). A study of Pakistani teachers' beliefs and perceptions about teaching and learning. Interdisciplinary Journal of Contemporary Research in Business, 4(5), 128-143.

Alzubi, A. A. F., \& Singh, M. K. M. (2017). The Use of Language Learning Strategies through Smartphones in Improving Learner Autonomy in EFL Reading among Undergraduates in Saudi Arabia. International Journal of English Linguistics, 7(6), 59-72. https://doi.org/10.5539/ijel.v7n6p59

Assor, A., Kaplan, H., \& Roth, G. (2002). The choice is good, but relevance is excellent: autonomy-enhancing and suppressing teacher behaviors predicting students' engagement in schoolwork. British Journal of Educational Psychology, 72, 261-278.

Bailey, C. A. (2007). A Guide to Qualitative Field Research (2nd ed.). Pine Forge Press: Thousand Oaks. https://doi.org/10.4135/9781412983204

Bajrami, L. (2015). Teacher's new role in language learning and in promoting learner autonomy. Procedia-Social and Behavioral Sciences, 199, 423-427. https://doi.org/10.1016/j.sbspro.2015.07.528

Balçıkanlı, C. (2010). Learner autonomy in language learning: Student teachers' beliefs. Australian Journal of Teacher Education, 35(1), 90-103.

Benson, P. (2011). Teaching and Researching Autonomy (2nd ed.). New York: Routledge.

Benware, C., \& Deci, E. L. (1984). Quality of learning with an active versus passive motivational set. American Educational Research Journal, 21, 755-765. https://doi.org/10.3102/00028312021004755

Boggiano, A. K., Flink, C., Shields, A., Seelbach, A., \& Barrett, M. (1993). Use of techniques promoting students' self-determination: Effects on students' analytic problem-solving skills. Motivation and Emotion, 17, 319-336. https://doi.org/10.1007/BF00992323

Borg, S., \& Al-Busaidi, S. (2011). Teachers' beliefs and practices regarding learner autonomy. ELT J. https://doi.org/10.1093/elt/ccr065

Camilleri, A. (1997). Introducing learner autonomy in initial teacher training. In H. Holec \& H. Irma (Eds.), Learner Autonomy. Strasbourg: Council of Europe.

Creswell, J. W. (2003). Research Design: Qualitative, Quantitative, and Mixed Methods Approaches (2nd ed.). Thousand Oaks, CA: SAGE Publications.

Dam, L. (1995). Learner Autonomy 3: From theory to classroom practice. Dublin: Authentik.

Deci, E. L., Schwartz, L., Sheinman, L., \& Ryan, R. M. (1981). An instrument to assess adults' orientations toward control versus autonomy in children: Reflections on intrinsic motivation and perceived competence. Journal of Educational Psychology, 73, 642-650. https://doi.org/10.1037/0022-0663.73.5.642 
Deci, E. L., Spiegel, N. H., Ryan, R. M., Koestner, R., \& Kauffman, M. (1982). Effects of performance standards on teaching styles: Behavior of controlling teachers. Journal of Educational Psychology, 74, 852-859. https://doi.org/10.1037/0022-0663.74.6.852

Duong, T. M., \& Seepho, S. (2014). Promoting learner autonomy: A qualitative study on EFL teachers' perceptions and their teaching practices. Proceedings of the International Conference: DRAL 2 / ILA 2014, $129-137$.

Dwee, C. Y., \& Anthony, E. M. (2017). Learner Autonomy in University English Classrooms: Teachers' Perceptions and Practices. International Journal of Applied Linguistics \& English Literature, 6(2), 19-25. https://doi.org/10.7575/aiac.ijalel.v.6n.2p.19

Ellis, G., \& Sinclair, B. (1989). Learning to learn. Cambridge: Cambridge University Press.

Esch, E. (1998). Promoting learner autonomy: Criteria for the selection of appropriate methods. In R. Pemberton, E. S. L. Li, W. W. F. Or, \& H. D. Pierson (Eds.), Taking control: Autonomy in language learning (pp. 35-48). Hong Kong: Hong Kong University Press.

Feryok, A. (2013). Teaching for learner autonomy: the teacher's role and sociocultural theory. Innovation in Language Learning and Teaching, 7(3), 213-225. https://doi.org/10.1080/17501229.2013.836203

Hesse-Biber, S., \& Leavy, P. (2006). The practice of qualitative research. Thousand Oaks: CA: Sage.

Higgs, J. (1988). Planning learning experiences to promote autonomous learning. In D. Boud (Ed.), Developing Student Autonomy in Learning (2nd ed., pp. 59-76). London: Kogan Page.

Holec, H. (1981). Autonomy and foreign language learning. Oxford: Pergamon Press.

Holec, H. (1987). The learner as manager: managing learning or managing to learn? In A. Wenden \& J. Rubin (Eds.), Learner strategies in language learning (pp. 145-156). Cambridge: Prentice-Hall.

Jang, H., Reeve, J. \& Halusic, M. (2016). A New Autonomy-Supportive Way of Teaching That Increases Conceptual Learning: Teaching in Students' Preferred Ways. The Journal of Experimental Education, 84(4), 686-701. https://doi.org/10.1080/00220973.2015.1083522

Khilji, S. E. (2003). To adapt or not to adapt: Exploring the role of national culture in human resource management. International Journal of Cross Cultural Management, 3(1), 109-132.

Koestner, R., Ryan, R. M., Bernieri, F., \& Holt, K. (1984). Setting limits on children's behavior: The differential effects of controlling versus informational styles on intrinsic motivation and creativity. Journal of Personality, 52, 233-248. https://doi.org/10.1111/j.1467-6494.1984.tb00879.x

Larsen-Freeman, D. (1986). Techniques and Principles in Language Teaching. Oxford: Oxford University Press.

Lightbown, P. M., \& Spada, N. (1990). Focus-on-form and corrective feedback in communicative language teaching. Second Language Acquisition, 12, 429-447.

Lincoln, Y. S., \& Guba, E. G. (1985). Naturalistic inquiry. Beverly Hills, CA: Sage.

Little, D. (1991). Learner autonomy: Definitions, issues and problems. Dublin: Authentik.

Little, D. (1995). Learning as dialogue: The dependence of learner autonomy on teacher autonomy. System, 23(2), 175-181. https://doi.org/10.1016/0346-251X(95)00006-6

Little, D. (2004). Learner Autonomy, Teacher Autonomy and the European Language Portolio. Retrieved from http://utc.fr/ untele/2004ppt/handouts/little.pdf

McDevitt, B. (1997). Learner Autonomy and the need for learner training. The Language Learning Journal, 16(1), 34-39. https://doi.org/10.1080/09571739785200251

Nakata, Y. (2014). Self-regulation: Why is it important for promoting learner autonomy in the school context? Studies in Self-Access Learning Journal, 5(4), 342-356.

Nasri, N., Eslami Rasekh, A., Vahid Dastjerdy, H., \& Amirian, Z. (2015). Promoting learner autonomy in an Iranian EFL high school context: Teachers' practices and constraints in focus. International Journal of Research Studies in Language Learning, 4(3), 91-105. https://doi.org/10.5861/ijrsll.2015.925.

Ng, S. F., \& Confessore, G., J. (2010). The relationship of multiple learning styles to levels of learner autonomy. International Journal of Self-directed Learning, 7(1), 1-13.

Nguyen, L. T. C., \& Gu, Y. (2012). Strategy-based instruction: A learner-focused approach to developing learner autonomy. Language Teaching Research, 17(1), 9-30. https://doi.org/10.1177/1362168812457528 
Omaggio, A. C. (1986). Teaching Language in Context: Proficiency-Oriented Instruction. Boston: Heinle and Heinle.

Pehrsson, R. S., \& Robinson, A. H. (1985). The SemanticOrganizer Approach to Writing and Reading Instruction. Rockville, Maryland: Aspen Publishers, Inc.

Reeve, J. (2006). Teachers as Facilitators: What Autonomy-Supportive Teachers Do and Why Their Students Benefit. The Elementary School Journal, 106(3), 225-236. https://doi.org/10.1086/501484

Reeve, J., Bolt, E., \& Cai, Y. (1999). Autonomy supportive teachers: How they teach and motivate students. Journal of Educational Psychology, 9, 537-548. https://doi.org/10.1037/0022-0663.91.3.537

Reeve, J., Jang, H., Carrell, D., Jeon, S., \& Barch, J. (2004). Enhancing students' engagement by increasing teachers autonomy support. Motivation and Emotion, 28, 147-169. https://doi.org/10.1023/B:MOEM.0000032312.95499.6f

Ryan, R. M., \& Deci, E. L. (2000). Self-determination theory and the facilitation of intrinsic motivation, social development and well-being. American Psychologist, 55, 68-76.

Ryan, R. M., \& Wendy, S. G. (1986). Origins and pawns in the classroom: Self-report and projective assessments of individual differences in children's perceptions. Journal of Personality and Social Psychology, 50, 550-558. https://doi.org/10.1037/0022-3514.50.3.550

Shapira, Z. (1976). Expectancy determinants of intrinsically motivated behavior. Journal of Personality and Social Psychology, 34, 1235-1244. https://doi.org/10.1037/0022-3514.34.6.1235

Truscott, J. (1996). The Case Against Grammar Correction in L2 Writing Classes. Language Learning, 46, 327-369. https://doi.org/10.1111/j.1467-1770.1996.tb01238.x

Ushioda, E. (2011). Why autonomy? Insights from motivation theory and research. Innovation in language learning and teaching, 5(2), 221-232. https://doi.org/10.1080/17501229.2011.577536

Voller, P. (1997). Does the Teacher Have a Role in Autonomous Language Learning? In P. Benson \& P. Voller (Eds.), Autonomy and Independence in Language Learning (pp. 98-113). London: Longman.

Xu, L. (2015). A Study on College English Teachers' Role in Developing Learner Autonomy. Theory and Practice in Language Studies, 5(2), 435-441.

Yan, S. (2012). Teachers' Roles in Autonomous Learning. Journal of Sociological Research, 3, 557-562. https://doi.org/10.5296/jsr.v3i2.2860

Yang, N. D. (1998). Exploring a new role for teachers: promoting learner autonomy. System, 26, 127-135. https://doi.org/10.1016/S0346-251X(97)00069-9

Yasmin, M., \& Sohail, A. (2017). A Creative Alliance between Learner Autonomy and English Language Learning: Pakistani University Teachers' Beliefs. Creativity Studies. https://doi.org/10.3846/23450479.2017.1406874

Yasmin, M., Sarkar, M., \& Sohail, A. (2016). Exploring English Language Needs of Hotel Industry in Pakistan: An Evaluation of Existing Teaching Material. Journal of Hospitality \& Tourism Education, 28(4), 202-213. https://dx.doi.org/10.1080/10963758.2016.1226846

Yasmin, M., Sohail, A., \& Mangrio, R. A. (2015). Myths Broken or Sustained: Representation of Women victims in Pakistani Media. Open Journal of Social Science, 3, 209-219. http://dx.doi.org/10.4236/jss.2015.37033

Yasmin, M., Sohail, A., Sarkar, M., \& Hafeez, R. (2017). Creative methods in transforming education using human resources. Creativity Studies, 10 (2), 145-158. https://doi.org/10.3846/23450479.2017.1365778

\section{Appendix A. Interview Question}

1) What should a teacher do to promote learner autonomy in or outside of classroom?

2) To what extent do you promote learner autonomy?

3) What sort of activities can contribute autonomy in learners? Mention any if you apply.

\section{Copyrights}

Copyright for this article is retained by the author(s), with first publication rights granted to the journal.

This is an open-access article distributed under the terms and conditions of the Creative Commons Attribution license (http://creativecommons.org/licenses/by/4.0/). 